\title{
DNA Repair Protein RAD51 Homolog 2
}

National Cancer Institute

\section{Source}

National Cancer Institute. DNA Repair Protein RAD51 Homolog 2. NCI Thesaurus. Code C90147.

DNA repair protein RAD51 homolog 2 (384 aa, $\sim 42 \mathrm{kDa}$ ) is encoded by the human RAD51B gene. This protein plays a role in DNA repair. 